\title{
Soil phosphorus dynamics as affected by Congo grass and $\mathbf{P}$ fertilizer
}

\author{
Ciro Antonio Rosolem*, Alexandre Merlin, Júlio Cesar Longo Bull
}

São Paulo State University/FCA - Dept. of Crop Science, R. José Barbosa de Barros, 1780 - 186010-307 - Botucatu, SP - Brazil.

*Corresponding author <rosolem@fca.unesp.br>

Edited by: Leônidas Carrijo Azevedo Melo
ABSTRACT: Some plant species can change soil phosphorus (P) availability and this may be an important tool in managing tropical high fixing phosphorus soils. An experiment was conducted to evaluate phosphorus transformations in the soil and phosphatase activity during periods of Congo grass (Brachiaria ruziziensis, Germain et Evrard) growth in two tropical soils receiving 20, $40,80,160 \mathrm{mg} \mathrm{dm}^{-3}$ of inorganic P. Plants were grown for 84 days in 8-L pots. Acid phosphatase activity, $\mathrm{P}$ in the microbial mass, soil organic and inorganic $\mathrm{P}$ and $\mathrm{P}$ accumulation by Congo grass were evaluated. Phosphorus fertilization increased soil $P$ availability, Congo grass yields and $\mathrm{P}$ accumulation in the plant. On average, less labile $\mathrm{P}$ forms in the soil were not changed by Congo grass; however, the $\mathrm{P}$ in the soil extracted with $\mathrm{HCl}$ ( $\mathrm{P}-\mathrm{Ca}$ - non labil form) decreased. This decrease may have resulted from the combination of the presence of grass and phosphatase capacity to dissolve less available $\mathrm{P}$ in the soil. Thus, soil exploration by Congo grass roots and the subsequent extraction of calcium phosphate may have increased the $\mathrm{P}$ concentration in the plant tissue. Despite the decrease in the $\mathrm{P}$ extracted from the soil with $\mathrm{HCl}$ resulting in increased labile $P$ forms in the soil, the effect of Congo grass on the availability of $P$ depends on the soil type. Keywords: phosphatase, soil fertility, crop rotation, brachiaria
Received October 17, 2013

Accepted January 20, 2014 a huge number of microorganisms that can mineralize $\mathrm{P}_{\mathrm{o}^{\prime}}$ such as fungi and bacteria. The phosphatase activity is sensitive to soil management and climate seasonality, and depending on its activity, organic $\mathrm{P}$ may or may not be available in the cropping systems. Therefore, these enzymes could be useful in evaluating soil quality, broadening the study and the meaning of soil fertility with the inclusion of a measureable biological component.

Root induced processes markedly affect $\mathrm{P}$ availability (Devau et al., 2011), and Congo grass may enhance soil $\mathrm{P}$ availability through a decrease in maximum soil P fixation capacity (Janegitz et al, 2013) and an increase in microorganism and acid phophatase activity in the rhizosphere. This more labile $\mathrm{P}$ could be available for the next crop. Congo grass has been used in Brazil as forage or cover crop in rotation with cash crops under no-till because it has vigorous shoot and root growth, which benefits nutrient cycling (Calonego and Rosolem, 2013) and soil properties (Garcia et al., 2013). This study aimed to evaluate the activity of acid phosphatases and $\mathrm{P}$ transformations during periods of Congo grass growth, as well as to assess a potential increase in organic $\mathrm{P}$ as affected by $\mathrm{P}$ availability.

\section{Materials and Methods}

bai, 1977). Acid phosphatases activity decreases with $\mathrm{P}_{\mathrm{i}}$ availability in the soil due to either an increase in $\mathrm{P}$ mineralization or $\mathrm{pH}$ (Rengel and Marschner, 2005). The decrease of $\mathrm{P}_{\mathrm{o}}$ in cropped pasture soil is closely related to the $\mathrm{P}$ concentration of the microorganisms' biomass (Brookes et al., 1984).

The contribution of $\mathrm{P}_{\mathrm{o}}$ to the total $\mathrm{P}$ available to the plant can be important for plant maintenance primarily in areas with pastures and forests, but this contribution can also be significant in areas cropped under no tillage, with adequate management of cover crops. There are
An experiment was conducted in a greenhouse, in 8-L pots filled with $9.2 \mathrm{~kg}$ of two soils (Table 1): a clayey Rhodic Hapludox (RH) and a Typic Haplustult (TH) (Soil Survey Staff, 2010). These soils were chosen because they are representative of Brazilian soils, $\mathrm{RH}$ was taken in Botucatu, state of São Paulo, Brazil $\left(22^{\circ} 49^{\prime} \mathrm{S}, 48^{\circ} 25^{\prime}\right.$ W, altitude $800 \mathrm{~m}$ ); while TH was taken in Luís Eduardo Magalhães, in the state of Bahia, Brazil (12 $12^{\circ} 31^{\prime \prime}$, $46^{\circ} 13^{\prime} 26^{\prime \prime} \mathrm{W}$, altitude $820 \mathrm{~m}$ ). Lime was applied (CaO: 39 
$\%, \mathrm{MgO}: 13 \%$ in order to increase base saturation to $70 \%$, and the soil was moistened to soil water retention capacity and kept moist for 60 days. This was done because it is closer to the soil environment where the forage is grown in rotation with cash crops. Next, $100 \mathrm{mg}$ $\mathrm{dm}^{-3}$ of $\mathrm{N}$ and $100 \mathrm{mg} \mathrm{dm}^{-3}$ of $\mathrm{K}$ were added as urea and potassium chloride, respectively. Phosphorus was added as triple superphosphate at $20,40,80,160 \mathrm{mg} \mathrm{dm}^{-3}$, and Congo grass (Brachiaria ruziziensis, Germain et Evrard, sin. Urocloa ruziziensis) was grown or not in the pots, with four replicates.

Congo grass seeds were pre-germinated in a germination chamber for $48 \mathrm{~h}$ at $25^{\circ} \mathrm{C}$ after dormancybreaking by immersion in concentrated sulfuric acid for $10 \mathrm{~min}$ and washing in distilled water, and transferred to the pots. Eight days after planting, they were thinned to four seedlings per pot. Soil moisture was maintained between 70 and $100 \%$ of the soil retention capacity, by weighing and replacing water loss daily. Congo grass was harvested $84 \mathrm{~d}$ after planting and dried in a forced air oven at $65{ }^{\circ} \mathrm{C}$ for $4 \mathrm{~d}$. Dry matter yields were then determined. Subsequently, the material was ground and $\mathrm{P}$ concentration in the tissue was determined using nitric-perchloric wet acid digestion. Part of the soil was dried under ambient temperature conditions and part was saved for microbial $\mathrm{P}$ analysis.

Soil $\mathrm{pH}\left(0.01 \mathrm{M} \mathrm{CaCl}_{2}\right)$ was determined after harvest. Acid phosphatase activity was estimated colorimetrically by determining the amount of $p$-nitrophenol released by the enzyme when the soil was incubated with a solution of $p$-nitrophenyl sodium phosphate and toluene at $37{ }^{\circ} \mathrm{C}$ for $1 \mathrm{~h}$ (Tabatabai and Bremner, 1969). Organic phosphorus was calculated as the difference between results from unburned and burned (muffle furnace at $550{ }^{\circ} \mathrm{C}$ for $2 \mathrm{~h}$ ) samples as in Olsen and Sommers (1982).

Soil samples were extracted using Hedley et al.'s (1982) P fractionation method, with modifications as proposed by Condron and Goh (1989). Specifically, 1.5 $\mathrm{g}$ of soil samples were quickly subjected to extraction conditions in sequential order. Shortly after, labile inorganic $\mathrm{P}$ was extracted with anion exchange resin. Next, labile inorganic and organic $\mathrm{P}$ were extracted with 0.5 $\mathrm{M} \mathrm{NaHCO}_{3}$, moderately labile organic $\mathrm{P}$ were extracted with $0.1 \mathrm{M} \mathrm{NaOH}, \mathrm{P}$ was extracted sequentiallywith 1

Table 1 - Chemical characteristics from two tropical soils (Rhodic Hapludox - RH and Typic Haplustult - TH) used in the experiment.

\begin{tabular}{|c|c|c|c|c|c|c|c|}
\hline Soil & $\mathrm{pH}$ & O.M. & $P^{(1)}$ & $\mathrm{H}+\mathrm{Al}$ & K & $\mathrm{Ca}$ & $\mathrm{Mg}$ \\
\hline & $\left(0.01 \mathrm{M} \mathrm{CaCl}_{2}\right)$ & $\mathrm{g} \mathrm{dm}^{-3}$ & $\mathrm{mg} \mathrm{dm}^{-3}$ & 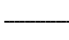 & $-\mathrm{mm}$ & $\mathrm{dm}$ & \\
\hline $\mathrm{RH}$ & 4.1 & 12 & 3 & 60 & 0.2 & 2 & 0 \\
\hline TH & 5.2 & 8 & 6 & 45 & 1.1 & 8 & 4 \\
\hline & \multicolumn{2}{|c|}{ Clay } & & Silt & \multicolumn{3}{|c|}{ Sand } \\
\hline RH & \multicolumn{2}{|c|}{750} & & 200 & \multicolumn{3}{|c|}{50} \\
\hline $\mathrm{TH}$ & \multicolumn{2}{|c|}{670} & & 210 & \multicolumn{3}{|c|}{20} \\
\hline
\end{tabular}

$\mathrm{M} \mathrm{HCl}$. Then, occluded inorganic and organic $\mathrm{P}$ from soil micro aggregates were extracted with $0.5 \mathrm{M} \mathrm{NaOH}$. Residual $\mathrm{P}$ was extracted with $\mathrm{H}_{2} \mathrm{SO}_{4}$, and total organic $\mathrm{P}$ was calculated as the difference between results obtained from unburned and burned samples. All of the samples were analyzed in triplicate. After these extractions the samples were digested with $\mathrm{H}_{2} \mathrm{SO}_{4}+\mathrm{H}_{2} \mathrm{O}_{2}$. $\mathrm{P}_{\mathrm{i}}$ was analyzed as in Dick and Tabatabai (1977) in the $\mathrm{NaHCO}_{3}$ and $\mathrm{NaOH}$ extracts. In addition, total $\mathrm{P}$ was analyzed after acid digestion.

The amount of $\mathrm{P}$ in the microbial mass was obtained by calculating the difference between the amount of $\mathrm{P}_{\mathrm{i}}$ extracted using $0.5 \mathrm{M} \mathrm{NaHCO}_{3}(\mathrm{pH} 8.5)$ from fresh soil fumigated with $\mathrm{CHCl}_{3}$ and the amount extracted from non-fumigated soil. Fresh soil was used because the amount of $\mathrm{P}$ that $\mathrm{CHCl}_{3}$ releases in dry soil is very low (Brookes et al., 1982).

The results of each soil were subjected to ANOVA as a $2 \times 5$ factorial (with and without plants and 5 $\mathrm{P}$ rates) design in completely randomized blocks with four replications. The parameters of $\mathrm{P}$ in the soil were correlated with $\mathrm{P}$ uptake by Congo grass. Means were compared using the t-test (LSD, $p<0.05)$. When appropriate, equations were fit to the results.

\section{Results}

Congo grass dry matter yields had a response to $\mathrm{P}$ rates regardless of soil type, up to $80 \mathrm{mg} \mathrm{kg}^{-1}$ of $\mathrm{P}$ (Figure 1). However, yields were higher in $\mathrm{RH}$ than in $\mathrm{TH}$. In addition, plant $\mathrm{P}$ concentrations increased linearly with fertilizer rates. Some plants can modify the soil chemical properties such as $\mathrm{pH}$ and the cation exchange

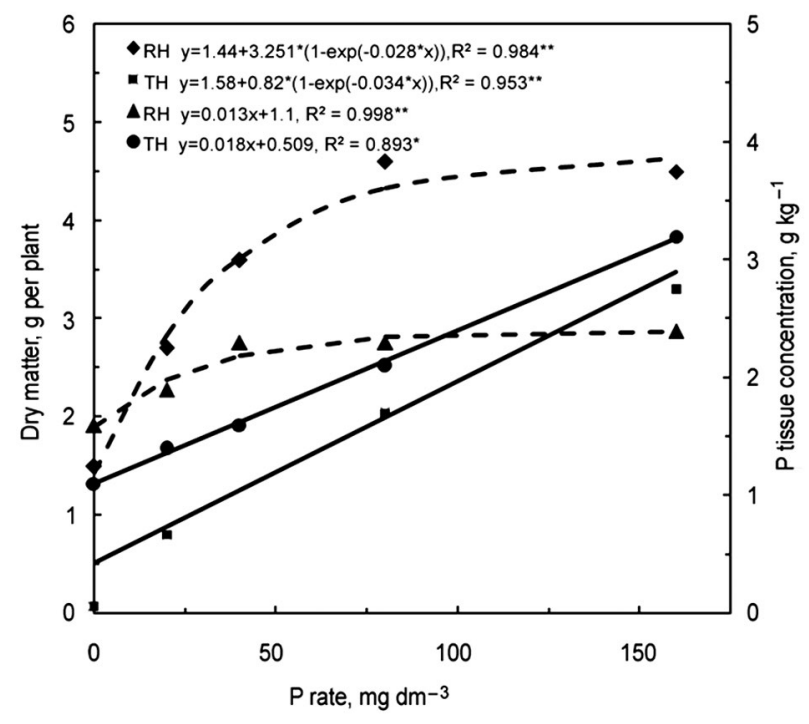

Figure 1 - Congo grass dry matter (dashed lines) and $P$ concentrations (solid lines) in the tissue as affected by $P$ rates in two tropical soils; RH: Rhodic Hapludox; $\mathrm{TH}$ : Typic Haplustult. ${ }^{*} \mathrm{R}^{2}$ Significant $(p>0.01) ;{ }^{*} \mathrm{R}^{2}$ Significant $(p>0.05)$. 
capacity by exuding organic acids in the rhizosphere (Devau et al., 2011). However, in the present experiment the average $\mathrm{pH}$ was 5.2 in $\mathrm{RH}$ and 5.4 in $\mathrm{TH}$ and it was not affected by phosphate fertilization or Congo grass (results not shown).

The microbial biomass $\mathrm{P}$ increased with $\mathrm{P}$ rates, with a larger increase in $\mathrm{RH}$ than in $\mathrm{TH}$ (Figure 2). The values of $\mathrm{P}$ in the microbial biomass were larger in the presence of grass $(p<0.05)$, with no interaction with $\mathrm{P}$ rates. For example, at the lowest rates of $\mathrm{P}$ the values observed in the absence and in the presence of grass were 11.9 and $14.6 \mathrm{\mu g} \mathrm{g}^{-1}$, respectively, reaching $43.3 \mu \mathrm{g} \mathrm{g}^{-1}$ for the largest rate of $\mathrm{P}$ added, in the presence of Congo grass in $\mathrm{RH}$ (Figure 2). In $\mathrm{TH}$ differences between the values observed in the presence and absence of grass were also significant as in $\mathrm{RH}(p<0.05)$, but in this case there was an interaction with $\mathrm{P}$ rates.

Acid phosphatase activity decreased with phosphate fertilization and increased in the presence of Congo grass (Figure $3, p<0.05$ ). This activity was, in general, higher in $\mathrm{RH}$, where the lowest rate of $\mathrm{P}$ resulted in the average production of $669 \mu \mathrm{g}$ of $\mathrm{p}$-nitrophenol $\mathrm{g}^{-1}$ $\mathrm{h}^{-1}$ while the largest rate resulted in an average value of $541 \mu \mathrm{g}$ of $\mathrm{p}$-nitrophenol $\mathrm{g}^{-1} \mathrm{~h}^{-1}$. The differences in acid phosphatase activity in $\mathrm{TH}$ samples were lower, with values of 568 and $481 \mu \mathrm{g}$ of p-nitrophenol $\mathrm{g}^{-1} \mathrm{~h}^{-1}$ at the lowest and largest rate of $\mathrm{P}$, respectively (Figure 3).

Phosphate fertilization up to $80 \mathrm{mg} \mathrm{kg}^{-1}$ increased soil labile P irrespective of grass cultivation (Figure 4), but the presence of Congo grass resulted in higher $\mathrm{P}$ availability in $\mathrm{RH}$. However, there was no effect on the inorganic labile fraction $\left(\mathrm{NaHCO}_{3}\right)$ of $\mathrm{P}$ (Table 2). For the $\mathrm{P}$ inorganic fraction extracted with $0.1 \mathrm{M} \mathrm{NaOH}$ there was a response to the added $\mathrm{P}$ and again there was no Congo grass effect (Table 2). A response to $\mathrm{P}$ fertilizer was also observed for $\mathrm{HCl}$ extracted-P, which was reduced after Congo grass cultivation.

Soil $\mathrm{P}_{\mathrm{i}}$ increased with $\mathrm{P}$ rates (Table 2). An increase in the fraction of non-labile $\mathrm{P}(0.5 \mathrm{M} \mathrm{NaOH})$ as affected by $\mathrm{P}$ fertilization was observed independently of grass cultivation (Table 2). The values of this non-labile $\mathrm{P}$ fraction were greater for $\mathrm{RH}$ than for $\mathrm{TH}$. There was no effect of $\mathrm{P}$ rates or the use of Congo grass on the $\mathrm{P}$ residual fraction (Table 2). Labile $\mathrm{P}_{\mathrm{o}}$ was affected by $\mathrm{P}$ application in both soils, but there was no effect of grass or interactions (Table 3$)$. There was no effect $(p<0.05)$ of treatments on other forms of $\mathrm{P}_{\text {。 }}$

As expected, $\mathrm{P}$ fertilization had no effect on the organic P complexed with iron and aluminum. Grass cultivation produced no effect $(p<0.05)$ on this fraction and there were no significant interactions between the treatments (Table 3).

\section{Discussion}

In general, $\mathrm{P}$ tissue concentrations in Congo grass were above the sufficiency range reported for tropical grasses (Malavolta et al., 1997), from 0.8 to $1.2 \mathrm{~g} \mathrm{~kg}^{-1}$.
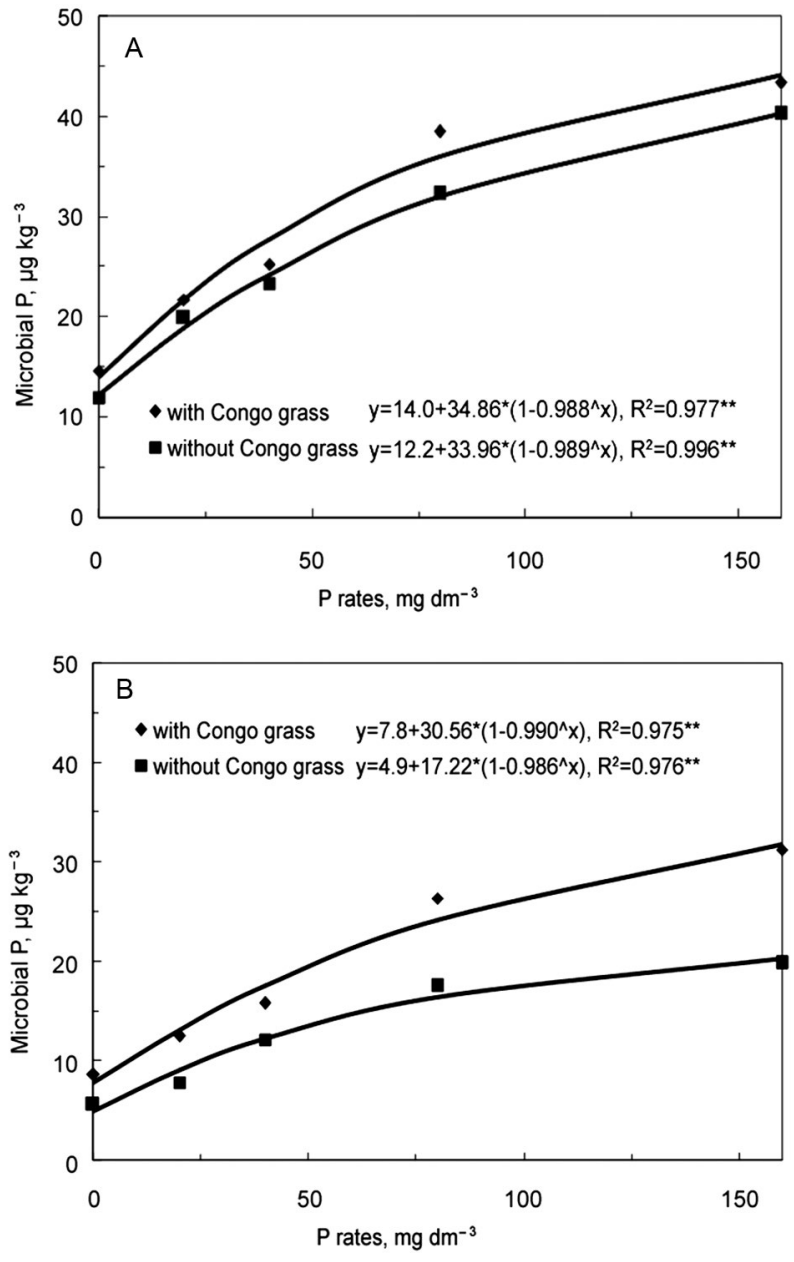

Figure 2 - Microbial $P$ as affected by $P$ rates (with and without Congo grass) in two tropical soils. A: Rhodic Hapludox; B: Typic Haplustult. ${ }^{*}{ }^{2}$ Significant $(p>0.01)$; ${ }^{*} R^{2}$ Significant $(p>0.05)$.

Even so, dry matter yields and $\mathrm{P}$ tissue concentrations increased with $\mathrm{P}$ application (Figure 1). $\mathrm{P}$ was immobilized in the soil with increased fertilization (Figures 2 A and B). This phenomenon is observed in soils where the management system allows for organic material accumulation on the surface, and conditions are favorable for microbial development. Similar data were obtained by Rheinheimer et al. (2002), who observed an increase in $\mathrm{P}$ stored in the microbial biomass after addition of $\mathrm{P}$. Immobilized $\mathrm{P}$ in the microbial biomass can be released into the soil by rupture of the microbial cells, and also by the interactions with the microfauna that feed on microorganisms and subsequently release these stored nutrients into the soil (Buchanan and King, 1992). The $\mathrm{P}$ contained in the biomass acts, therefore, as a protection for this nutrient, diminishing its fixation by soil colloids (Paul and Clark, 1996) and increasing the efficiency of phosphate fertilization in the long range by immobilizing part of the $\mathrm{P}$ from the fertilizer into the biomass. 

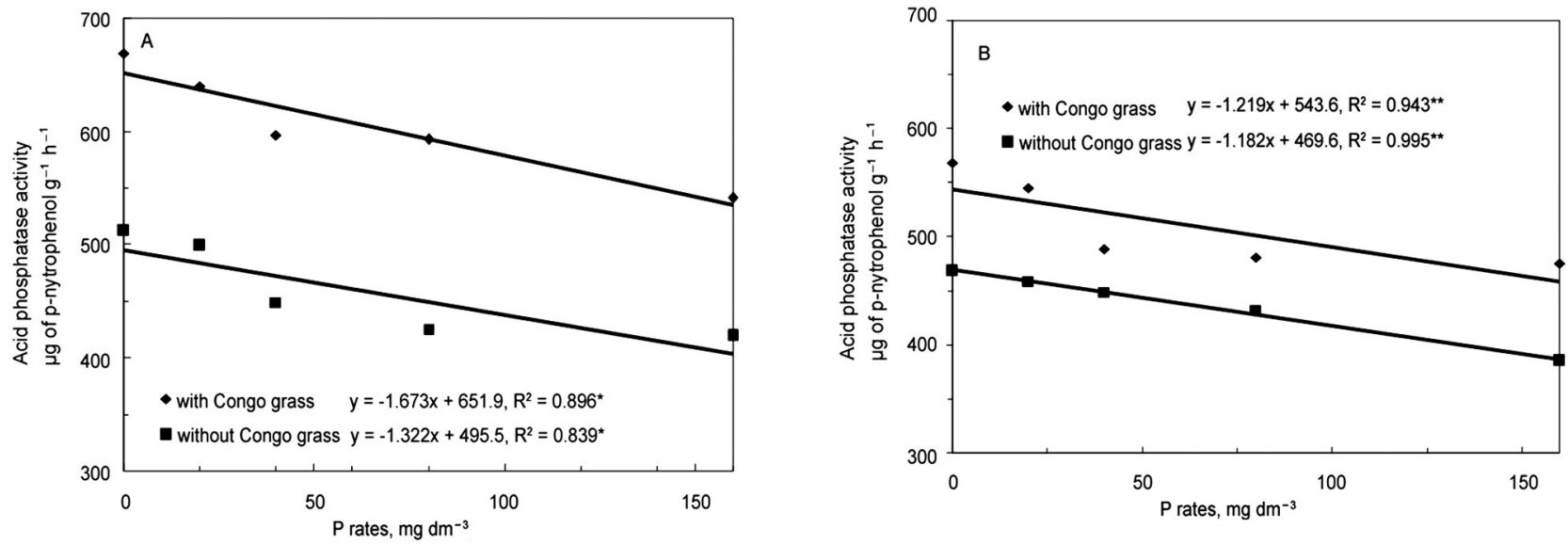

Figure 3 - Acid phosphatase activity ( $\mu$ g de $\mathrm{p}$-nitrophenol $\mathrm{g}^{-1} \mathrm{~h}^{-1}$ ) as affected by $\mathrm{P}$ rates (with and without Congo grass) in two tropical soils. A: Rhodic Hapludox; B: Typic Haplustult. ${ }^{*} \mathrm{R}^{2}$ Significant $(p>0.01) ;{ }^{*} \mathrm{R}^{2}$ Significant $(p>0.05)$.
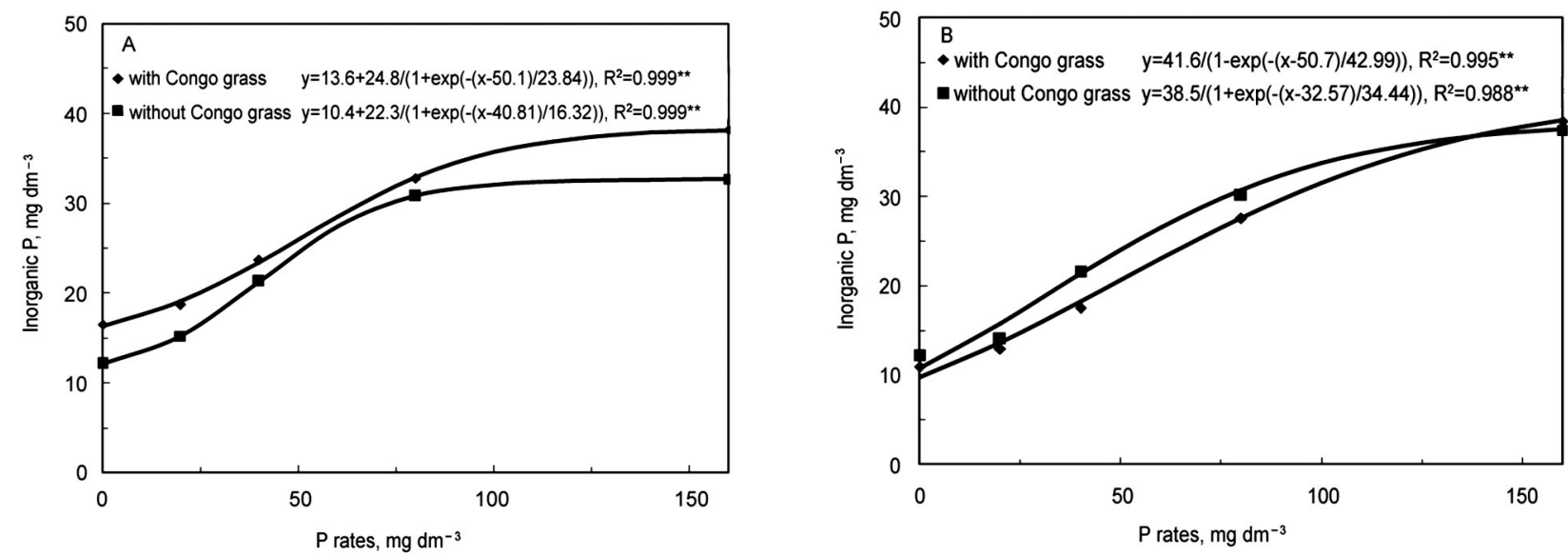

Figure 4 - Inorganic available $P$ extracted with pearl resin as affected by $P$ rates (with and without Congo grass) in two tropical soils A: Rhodic Hapludox; B: Typic Haplustult. ${ }^{*} \mathrm{R}^{2}$ Significant $(p>0.01)$; ${ }^{*} \mathrm{R}^{2}$ Significant $(p>0.05)$.

In addition to the $\mathrm{P}$ microbial biomass, the action of phosphate solubilizing microorganisms, the mycorrhizal fungi, and acid and alkaline phosphatases production by microorganisms are responsible for the mineralization of $\mathrm{P}_{\mathrm{o}}$ (Dick and Tabatabai, 1993). In some species, the activity of enzymes such as acid and alkaline phosphatases in dissolving less soluble phosphates has been demonstrated (Rengel and Marschner, 2005), including ruzigrass - Brachiaria ruziziensis, Germain et Evrard (Louw-Gaume et al., 2010). In the experiment reported herein, addition of $\mathrm{P}$ decreased acid phosphatase activity in both soils (Figure $3 \mathrm{~A}$ and B), as expected (Bünemann et al., 2012). According to Dick and Tabatabai (1993), microorganisms would be the main sources of phosphatases in the soil. Thus, their large biomass, high metabolic activity and short life span, with several generations per year, would result in the production and release of large amounts of extracellular enzymes.
In sequence, anion exchange resin (AER) and bicarbonate extracted the amount of labile $\mathrm{P}_{\mathrm{i}}$. A high availability of the bicarbonate fraction has been observed by most of the authors who have worked with soil P fractionation, indicating that the amounts extracted by the AER do not represent all of the available soil P (Hedley et al., 1982; Guo and Yost, 1998). In the present study, soil labile $\mathrm{P}\left(\mathrm{NaHCO}_{3}-\mathrm{P}\right)$ fractions $\mathrm{P}$ were increased by $\mathrm{P}$ fertilization. However, Congo grass did not alter the labile inorganic fraction of $\mathrm{P}$ (Table 2), but increased AER $\mathrm{P}$ in one of the soils, the Rodhic Hapludox (Figure 4), regardless of $\mathrm{P}$ rates. The increase in acid phosphatase was higher in $\mathrm{RH}$, which may have affected $\mathrm{P}$ availability. Reports of phosphate fertilization promoting alterations in the labile $\mathrm{P}$ fraction exist, mainly when soluble sources of $P$ are used (Olibone and Rosolem, 2010). An increase in the labile organic fraction with rates of $\mathrm{P}$ has also been observed (Table 3). The observed effects with 
Table 2 - Soil inorganic P fractions: labile, bound to Iron and Aluminum (P-Fe/Al), bound to Calcium (P-Ca), non Labile, residual and total inorganic as affected by $\mathrm{P}$ rates, and with or without Congo grass in two tropical soils (Rhodic Hapludox - RH and Typic Haplustult - $\mathrm{TH}$ ).

\begin{tabular}{|c|c|c|c|c|c|c|c|c|c|c|c|c|}
\hline \multirow{2}{*}{$P$ rates $\left(\mathrm{mg} \mathrm{dm}^{-3}\right)$} & \multicolumn{2}{|c|}{$\mathrm{NaHCO}_{3} \mathrm{P}$} & \multicolumn{2}{|c|}{$0.1 \mathrm{M} \mathrm{NaOH}-\mathrm{P}$} & \multicolumn{2}{|c|}{$\mathrm{HCl}-\mathrm{P}$} & \multicolumn{2}{|c|}{$0.5 \mathrm{M} \mathrm{NaOH}-\mathrm{P}$} & \multicolumn{2}{|c|}{ Residual $\mathrm{P}$} & \multicolumn{2}{|c|}{ Total P } \\
\hline & With & Without & With & Without & With & Without & With & Without & With & Without & With & Without \\
\hline & & & & $-\mathrm{mg} \mathrm{dm}^{-3}$ & & & 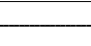 & & & & & \\
\hline & & & & & & & RH & & & & & \\
\hline 0 & 22.9 & 21.8 & 32.1 & 34.3 & 3.8 & 8.8 & 18.9 & 17.2 & 45.6 & 44.2 & 369 & 356 \\
\hline 20 & 23.7 & 22.5 & 33.9 & 36.5 & 10.1 & 14.5 & 21.9 & 20.9 & 48.6 & 45.1 & 421 & 389 \\
\hline 40 & 30.7 & 29.3 & 35.1 & 36.8 & 21.7 & 21.4 & 25.2 & 24.5 & 44.3 & 44.6 & 456 & 412 \\
\hline 80 & 34.8 & 33.8 & 32.5 & 33.1 & 16.5 & 19.4 & 26.7 & 25.8 & 46.2 & 46.9 & 489 & 436 \\
\hline 160 & 36.1 & 35.9 & 33.6 & 32.9 & 13.5 & 17.2 & 29.1 & 28.6 & 47.5 & 45.3 & 512 & 472 \\
\hline Average & 29.6 & 28.6 & 33.4 & 34.7 & 13.1 & 16.2 & 24.3 & 23.4 & 46.4 & 45.2 & 449 & 413 \\
\hline Prates (D) & $2.5^{*}$ & $3.1^{*}$ & $2.2^{*}$ & $2.2^{*}$ & $3.9^{*}$ & $3.9^{*}$ & $3.6^{*}$ & $3.6^{*}$ & ns & ns & $17.2^{*}$ & $17.2^{*}$ \\
\hline Congo grass (B) & $\mathrm{ns}^{(1)}$ & ns & ns & ns & $2.5^{*}$ & $2.5^{*}$ & ns & ns & ns & ns & ns & ns \\
\hline \multirow[t]{2}{*}{$\mathrm{D} \times \mathrm{B}$} & ns & ns & ns & ns & ns & ns & ns & ns & ns & ns & ns & ns \\
\hline & & & & & & & TH & & & & & \\
\hline 0 & 18.2 & 17.5 & 28.6 & 30.1 & 1.9 & 3.2 & 21.5 & 18.5 & 38.9 & 35.6 & 286 & 245 \\
\hline 20 & 19.3 & 18.5 & 28.1 & 32.8 & 9.2 & 12.4 & 20.7 & 21.1 & 37.2 & 35.1 & 302 & 269 \\
\hline 40 & 21.5 & 21.9 & 29.7 & 34.6 & 13.7 & 14.6 & 22.6 & 23.6 & 37.9 & 34.7 & 334 & 318 \\
\hline 80 & 21.9 & 19.4 & 31.2 & 34.9 & 12.9 & 13.6 & 23.5 & 24.3 & 38.0 & 34.3 & 359 & 349 \\
\hline 160 & 22.5 & 21.4 & 33.2 & 36.2 & 14.8 & 19.6 & 24.5 & 23.7 & 39.5 & 35.8 & 383 & 371 \\
\hline Average & 20.6 & 19.7 & 30.1 & 33.7 & 10.5 & 12.6 & 22.5 & 22.2 & 38.3 & 35.1 & 332 & 310 \\
\hline$P$ rates $(D)$ & 2.1 & 2.4 & $2.6^{*}$ & ns & ns & ns & $2.1^{*}$ & $2.1^{*}$ & ns & ns & $12.5^{\star}$ & $12.5^{*}$ \\
\hline Congo grass (B) & ns & ns & ns & ns & $3.1^{*}$ & $3.1^{*}$ & ns & ns & ns & ns & ns & ns \\
\hline$D \times B$ & ns & ns & ns & ns & ns & ns & ns & ns & ns & ns & ns & ns \\
\hline
\end{tabular}

${ }^{(1)}$ ns - non significant; * ${ }^{2} S D(p<0.05)$.

Table 3 - Organic $P$ fractions: labile $\left(\mathrm{NaHCO}_{3}\right), \mathrm{P}$ adsorbed to iron and aluminum $(0.1 \mathrm{M} \mathrm{NaOH})$, non labile $(0.5 \mathrm{M} \mathrm{NaOH})$ and total as affected by $\mathrm{P}$ rates (with or without Congo grass) in two tropical soils (Rodhic Hapludox - RH and Typic Haplustult - TH).

\begin{tabular}{|c|c|c|c|c|c|c|c|c|}
\hline \multirow{2}{*}{$P$ rates $\left(\mathrm{mg} \mathrm{dm}^{-3}\right)$} & \multicolumn{2}{|c|}{$\mathrm{NaHCO}_{3} \mathrm{P}$} & \multicolumn{2}{|c|}{$0.1 \mathrm{M} \mathrm{NaOH}-\mathrm{P}$} & \multicolumn{2}{|c|}{$0.5 \mathrm{M} \mathrm{NaOH}-\mathrm{P}$} & \multicolumn{2}{|c|}{ Total P } \\
\hline & With & Without & With & Without & With & Without & With & Without \\
\hline & 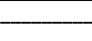 & $\mathrm{mg} \mathrm{dm}^{-3}$ & - & & & & & \\
\hline & & & & $\mathrm{Rl}$ & & & & \\
\hline 0 & 9.8 & 12.8 & 17.8 & 16.8 & 30.8 & 30.9 & 96.2 & 89.6 \\
\hline 20 & 10.7 & 14.9 & 16.5 & 17.8 & 31.5 & 29.8 & 98.8 & 91.2 \\
\hline 40 & 12.5 & 16.3 & 18.9 & 17.1 & 32.5 & 30.1 & 97.3 & 93.8 \\
\hline 80 & 17.9 & 17.9 & 19.2 & 18.3 & 31.6 & 29.2 & 101.2 & 94.1 \\
\hline 160 & 20.5 & 19.2 & 19.7 & 18.7 & 32.0 & 31.2 & 102.4 & 94.5 \\
\hline Average & 14.2 & 16.2 & 18.4 & 17.7 & 31.6 & 29.5 & 99.1 & 92.6 \\
\hline$P$ rates (D) & $4.3^{*}$ & $4.3^{*}$ & $\mathrm{~ns}^{1}$ & ns & ns & ns & ns & ns \\
\hline Congo grass (B) & ns & ns & ns & ns & ns & ns & ns & ns \\
\hline \multirow[t]{2}{*}{$\mathrm{D} \times \mathrm{B}$} & ns & ns & ns & ns & $\mathrm{ns}$ & ns & ns & ns \\
\hline & \multicolumn{8}{|c|}{$\mathrm{TH}$} \\
\hline 0 & 7.8 & 15.3 & 15.4 & 13.2 & 26.9 & 27.2 & 64.5 & 65.0 \\
\hline 20 & 8.9 & 14.6 & 14.1 & 13.8 & 25.8 & 26.5 & 67.2 & 64.2 \\
\hline 40 & 10.5 & 17.9 & 14.8 & 14.0 & 25.1 & 26.8 & 66.8 & 64.8 \\
\hline 80 & 12.7 & 16.9 & 15.6 & 14.3 & 26.4 & 26.4 & 65.8 & 65.4 \\
\hline 160 & 13.5 & 21.5 & 16.8 & 15.9 & 27.1 & 27.3 & 66.2 & 66.2 \\
\hline Average & 10.6 & 17.2 & 15.3 & 14.2 & 26.2 & 26.0 & 66.1 & 65.1 \\
\hline $\mathrm{P}$ rates (D) & $5.9^{*}$ & $5.9^{*}$ & ns & ns & ns & ns & ns & ns \\
\hline Congo grass (B) & ns & ns & ns & ns & ns & ns & ns & ns \\
\hline$D \times B$ & ns & ns & ns & ns & ns & ns & ns & ns \\
\hline
\end{tabular}

${ }^{(1)}$ ns - non significant; * $\operatorname{LSD}(p<0.05)$. 
grass cultivation are most likely due to the increased availability of $\mathrm{P}_{\mathrm{i}}$ from the fertilizer. Plants use organic sources of $\mathrm{P}$ almost as efficiently as mineral sources, given the hydrolysis of $\mathrm{P}_{\mathrm{o}^{\prime}}$ liberating $\mathrm{P}_{\mathrm{i}}$ (Tarafdar and Claassen, 1988). The organic soil $P$ can act as a source or sink for the available $\mathrm{P}$, depending on soil management and fertilization techniques used. The increase in $\mathrm{P}$ availability on the soil surface layers with the adoption of no-till can result in a significant transformation of $\mathrm{P}_{\mathrm{i}}$ into $\mathrm{P}_{\mathrm{o}}$.

The fraction of $\mathrm{P}$ extracted with $0.1 \mathrm{M} \mathrm{NaOH}$ generally increased with $\mathrm{P}$ application, although no significant effects of Congo grass cultivation or interactions were observed (Table 2). Schoninger et al. (2012) observed that brachiaria grass reduced the most available $\mathrm{P}$ forms only in the $0-1 \mathrm{~mm}$ layer from the rhizosphere. Under field conditions, a large amount of $\mathrm{P}$ added as fertilizer is adsorbed in soil and remains in moderately labile fractions (Pavinato et al., 2009). As expected, the rates of $\mathrm{P}$ did not have an effect on the organic $\mathrm{P}$ forms extracted with $0.1 \mathrm{M} \mathrm{NaOH}$ (Table 3).

The $\mathrm{P}$ extracted with $\mathrm{HCl}$ represents the calcium phosphate that can be provided from primary minerals in the soil, or in other words, calcium phosphates formed "in situ" (Magid et al., 1996), and also from the addition of phosphate fertilizers. This fraction is considered unavailable for the majority of plant species (Tiessen et al., 1984). Alterations in P-Ca levels were observed in the present experiment and the largest values were obtained with $17.5 \mathrm{mg} \mathrm{dm}^{-3}$ of $\mathrm{P}$ (Table 2). The data presented confirm the ability of Congo grass to use soil $\mathrm{P}$ forms of lower lability. The most common mechanism of $\mathrm{P}$ solubilization by plants and microorganisms is the exudation of organic acids, mainly citrate, malate and oxalate (Richardson et al., 2011), and it has been shown that Congo grass can exude organic acids in the rhizosphere (Wenzl et al., 2001).

The increases observed in non-labile $\mathrm{P}$ fraction (0.5 $\mathrm{M} \mathrm{NaOH}$ ) are attributed to the addition of the phosphate fertilizer (Table 2). The absence of an effect in the non-labile organic forms can be attributed to the low lability of this fraction in the soil due to high ionic strength exerted by the extraction with $0.5 \mathrm{M} \mathrm{NaOH}$. This fraction is considered to complement the inorganic and organic forms obtained by the extraction with $0.1 \mathrm{M}$ $\mathrm{NaOH}$ (Hedley et al., 1982).

The increases in the total $\mathrm{P}_{\mathrm{i}}$ fraction are attributed to the rate of $\mathrm{P}$ applied as treatments (Table 2). In no-till systems, the P-total values become larger over time, favoring the cycling of the nutrient into the soil, increasing the activity of the microorganisms and, consequently, the mineralization of $\mathrm{P}_{0}$. Pavinato et al. (2009) observed that phosphate fertilizer promoted $\mathrm{P}$ accumulation in less available fractions in the soil and, eventually this phosphorus could migrate to more labile fraction and be available to plants. Thus, the weathering factors and the presence of plants seem to be very important in the dynamics of $\mathrm{P}$, besides the actual application of phosphate fertilization.
The $\mathrm{P}_{\mathrm{o}}$ fraction was not affected by the grass. The effect of cover crops, mainly legumes, enhancing $\mathrm{P}$ availability has been observed before (Kamh et al., 1999; Richadson et al. 2011; Hassan et al., 2013), but results on the effect of no-till on available $\mathrm{P}$ are inconclusive and depend on the soil type (Zibilske et al., 2002; Pavinato et al., 2009; Devau et al., 2011). However, these results were obtained in a pot experiment where roots were very close together and the proportion of rhizosphere soil is higher than it would be under field conditions. Hence, the magnitude of these changes may not be sufficient to foster an improvement in the nutrition of subsequent crops in a rotation system.

\section{Conclusions}

Congo grass dry matter yields, as well as plant $\mathrm{P}$ accumulation increases with the addition of $\mathrm{P}$ fertilizer, which lead to an increase in $\mathrm{P}$ accumulation in the soil microbial biomass. Phosphorus fertilization decreases soil acid phosphatase activity, which is increased by Congo grass. Congo grass promotes alterations in some $\mathrm{P}$ fractions, and is able to take up $\mathrm{P}$ from less labile pools. It may also increase resin extracted $\mathrm{P}$, but it depends on the soil. The introduction of Congo grass in the rotation may enhance $\mathrm{P}$ use efficiency of the system over time. The effects can be high $\mathrm{P}$ uptake efficiency including the exploration of less labile forms along with vigorous growth and $\mathrm{P}$ accumulation in the plant.

\section{Acknowledgements}

This research was funded by FAPESP (The State of São Paulo Research Foundation) and CNPq (National Council for Scientific and Technological Development).

\section{References}

Brookes, P.C.; Powlson, D.S.; Jenkinson, D.S. 1982. Measurement of microbial biomass phosphorus in soil. Soil Biology and Biochemistry 14: 319-329.

Brookes, P.C.; Powlson, D.S.; Jenkinson, D.S. 1984. Phosphorus in the microbial biomass. Soil Biology and Biochemistry 16: 169-175.

Buchanan, M.; King, L.D. 1992. Seasonal fluctuations in soil microbial biomass carbon, phosphorus, and activity in no-till and reduced-chemical-input maize agroecosystems. Biology and Fertility of Soils 13: 211-217.

Bünemann, E.K.; Oberson, A.; Liebisch, F.; Keller, F.; Annaheim, K.E.; Huguenin-Elie, O.; Frossard, E. 2012. Rapid microbial phosphorus immobilization dominates gross phosphorus fluxes in a grassland soil with low inorganic phosphorus availability. Soil Biology and Biochemistry 51: 84-95.

Calonego, J; Rosolem, C.A. 2013. Phosphorus and potassium balance in a corn-soybean rotation under no-till and chiseling. Nutrient Cycling in Agroecosystems 96: 123-131. 
Cross, A.F.; Schlesinger, W.H.A. 1995. Literature review and evaluation of the Hedley fractionation: applications to the biogeochemical cycle of soil phosphorus in natural ecosystems. Geoderma 64: 197-214.

Dick, W.A.; Tabatabai, M.A. 1977. Determination of orthophosphate in aqueous solutions containing labile organic and inorganic phosphorus compounds. Journal of Environmental Quality 6: 82-85.

Dick, W.A.; Tabatabai, M.A. 1993. Significance and potential uses of soil enzymes. p. 95-127. In: Metting, J.R., ed. Soil microbial ecology applications in agricultural and environmental management. Marcel Dekker, New York, NY, USA.

Devau, N.; Hinsinger, P.; Cadre, E.; Gérard, F. 2011. Root-induced processes controlling phosphate availability in soils with contrasted P-fertilized treatments. Plant and Soil 348: 203-218.

Duputel, M.; Devau, N.; Brossard, M.; Jaillard, B.; Hinsinger, P.; Gérard, F. 2013. Citrate adsorption can decrease soluble phosphate concentration in soils: result of theoretical modeling. Applied Geochemistry 35: 120-131.

Eivazi, F.; Tabatabai, M.A. 1977. Phosphatases in soils. Soil Biology and Biochemistry 10: 545-551.

Garcia, R.A.; Li, Y.; Rosolem, C.A. 2013. Soil organic matter and physical attributes affected by crop rotation under no-till. Soil Science Society of America Journal 77: 1724-1731.

Guo, F.; Yost, R.S. 1988. Partitioning soil phosphorus into three discrete pools of differing availability. Soil Science 163: 822833.

Hassan, M.H.; Hasbullah, H.; Marschner, P. 2013. Growth and rhizosphere $\mathrm{P}$ pools of legume-wheat rotations at low $\mathrm{P}$ supply. Biology and Fertility of Soils 49: 41-49.

Hedley, M.J.; Stewart, J.W.B.; Ghauhan, B.S. 1982. Changes in inorganic soil phosphorus fractions induced by cultivation practices and laboratory incubations. Soil Science Society of America Journal 46: 970-976.

Janegitz, M.C.; Inoue, B.S.; Rosolem, C.A. 2013. Soil phosphorus pools as affected by brachiaria and white lupin. Ciência Rural 43: 1381-1386.

Kamh, M.; Horst, W.J.; Amer, F.; Mostafa, H.; Maier, P. 1999. Mobilization of soil and fertilizer Phosphate by cover crops. Plant and Soil 211: 19-27.

Louw-Gaume, A.E.; Rao, I.M.; Gaume, A.J.; Frossard, E. 2010. A comparative sudy on plant growth and root plasticity responses of two Brachiaria forage grasses grown in nutrient solution at low and high phosphorus supply. Plant and Soil 328: 155-164.

Magid, J.; Tiessen, H.; Condron, L.M. 1996. Dynamics of organic phosphorus in soils under natural and agricultural ecosystems. p. 429-466. In: Piccolo, A., ed. Humic substances. Elsevier, Amsterdam, The Netherlands.

Malavolta, E.; Vitti, G.C.; Oliveira, A.S. 1997. Assessment of Nutritional Status of Plants: Principles and Applications = Avaliação do Estado Nutricional das Plantas: Princípios e Aplicações. 1997. Potafos, Piracicaba, SP, Brazil.
Olibone, D.; Rosolem, C.A. 2010. Phosphate fertilization and phosphorus forms in an Oxisol under no-till. Scientia Agricola 67: 465-471.

Olsen, S.R.; Sommers, L.E. 1982. Phosphorus. p. 403-430. In: Page, A.L., Miller, R.H., Keeney, Q.R., eds. Methods of soil analysis. Part 2. Chemical and microbiological properties. 2ed. Soil Science Society of America, Madison, WI, USA.

Pavinato, P.S.; Merlin, A.; Rosolem, C.A. 2009. Phosphorus fractions in Brazilian Cerrado soils as affected by tillage. Soil and Tillage Research 105: 149-155.

Paul, E.A.; Clark, F.E. 1996. Soil Microbiology and Biochemistry. Academic Press, San Diego, CA, USA.

Rengel, Z.; Marschner, P. 2005. Nutrient availability and management in the rhizosphere: exploiting genotypic differences. New Phytologist 168: 305-312.

Rheinheimer, D.S.; Anghinoni, I.; Flores, A.F. 2002. Organic and inorganic phosphorus as characterized by phosphorus-31 nuclear magnetic resonance in subtropical soils under management systems. Communications in Soil Science and Plant Analysis 33: 1853-1871.

Richardson, A.E.; Lynch, J.P.; Ryan, P.R,; Delhaize, E.; Smith, F.A.; Smith, S.E.; Harvey, P.H.; Ryan, M.H.; Venecklaas, E.J.; Lambers, H.; Oberson, A.; Culvenor, R.A.; Simpson, R.J. 2011. Plant and microbial strategies to improve the phosphorus efficiency of agriculture. Plant and Soil 349: 121-156.

Schoninger, E.; Gatiboi, L.C.; Ernani, P.R. 2012. Rhizosphere pH and phosphorus forms in an Oxisol cultivated with soybean, brachiaria grass, millet and sorghum. Scientia Agricola 69: 259264.

Soil Survey Staff. 2010. Keys to Soil Taxonomy. 11ed. USDANRCS, Washington, DC, USA.

Tabatabai, M.A.; Bremner, J.M. 1969. Use of p-nitrophenyl phosphate for assay of soil phosphatase activity. Soil Biology and Biochemistry 1: 301-307.

Tarafdar, J.C.; Claassen, N. 1988. Organic phosphorus compounds as a phosphorus source for higher plants through the activity of phosphatases produced by plant roots and microorganisms. Biology and Fertility of Soils 5: 308-312.

Tiessen, H.; Stewart, J.W.B.; Cole, C.V. 1984. Pathways of phosphorus transformations in soils of differing pedogenesis. Soil Science Society of America Journal 48: 853-858.

Wenzl, P.; Pantiño, G.M.; Chave, A.L.; Mayer, J.E.; Rao, I.M. 2001. The high level of Aluminum resistance in signalgrass is not associated whith known mechanisms of external aluminum detoxification in root apices. Plant Physiology 125: 1473-1484.

Zibilske, L.M.; Bradford, J.M.; Smart, J.R. 2002. Conservation tillage induced changes in organic carbon, total nitrogen and available phosphorus in a semi-arid alkaline subtropical soil. Soil and Tillage Research 66: 153-163. 